\title{
Transfer of elements from paddy soils into different parts of rice plants (Oryza sativa L.) and the resulting health risks for the Vietnamese population
}

\author{
Sự vận chuyển các nguyên tố từ đất vào các phần của cây lúa (Oryza sativa L.) và đánh giá \\ các rủi ro sức khỏe đối với người dân Việt Nam
}

\author{
NGUYEN, Thuy Phuong1*; RUPPER, Hans²; PASOL, Tino²; SAUER, Benedikt²
}

${ }^{1}$ Faculty of Land Resources and Agricultural Environment, University of Agriculture and Forestry, Hue University. 102 Phung Hung Street, Hue City, Vietnam; 'Faculty of Geoscience and Geography, Georg-August-University Göttingen, Goldschmidtstraße 3, 37077 Göttingen, Germany

\begin{abstract}
The uptake of elements from paddy soils into shoot, husk, and unpolished grain of rice plants was investigated in Mekong, Huong, and Red River areas in Vietnam. The transferability of most studied soil elements into plant parts decreases in the order: shoot > husk > grain. Exceptions are $\mathrm{Mg}, \mathrm{S}, \mathrm{Cd}, \mathrm{Cu}, \mathrm{Zn}$, and Mo, whose transfer drops in the order: shoot $>$ grain $>$ husk, the transfer of $\mathrm{P}$ falls in the order grain $>$ shoot $>$ husk. The translocation of the most health relevant elements into the different plant parts is affected by soil parameters like $\mathrm{pH}$, organic matter, Fe- and Mn-phases, and clay minerals. Health risk assessment approaches for the average daily rice consumption are performed for noncancer risk (Hazard Index - HI) including the elements $\mathrm{As}, \mathrm{Cd}, \mathrm{Pb}, \mathrm{Co}, \mathrm{Cu}, \mathrm{Mn}, \mathrm{Mo}$, and $\mathrm{Ni}$ as well as for cancer risk for the elements As and Pb (Incremental Lifetime Cancer Risk - $\sum$ ILCR). All rice studied grain samples exceed the safe HI-index of below $1.81 \%$ of the grain samples were within the level of concern ranging between $1.4<\mathrm{HI}<5,18 \%$ varied between $5<\mathrm{HI}<8.4$, although their corresponding soils showed only a little pollution. $\mathrm{Cd}, \mathrm{As}, \mathrm{Mn}$, and Pb were the most important elements causing non-cancer risks for rice-consuming people. The cancer-risk values $\sum$ ILCR were mean $2.2 \times 10^{-3}$ and are considerably higher than the safe threshold of $10^{-4}$ to $10^{-6}$. Arsenic is the dominant factor for cancer risk. Rice-eating people living in Red River and Huong River areas face mainly health risks of exposure to As and Cd in the Mekong River area in addition to $\mathrm{Pb}$.
\end{abstract}

\begin{abstract}
Sự di chuyển của các nguyên tố từ đất vào các bộ phận khác nhau của cây lúa được tiến hành nghiên cứu tại cùng đồng bằng sông Mekông và sông Hồng, và tại sông Hương, và sông Hồng ở Việt Nam. Sự vận chuyển của hầu hết các nguyên tố đi vào cây lúa có xu hướng giảm dần theo thứ tự: thân > vỏ trấu > hạt. Ngoại trừ sự vận chuyển của các nguyên tố $\mathrm{Mg}, \mathrm{S}, \mathrm{Cd}, \mathrm{Cu}, \mathrm{Zn}$, và Mo giảm dần theo thứ tự: thân > hạt > vỏ trấu; và nguyên tố P giảm dần từ: hạt > thân > vỏ trấu. Sự vận chuyển các nguyên tố vào các bộ phận của cây bị ảnh hưởng bởi các điều kiện của đất như pH, hàm lượng chất hữu cớ, dạng Fe và Mn, và các khoáng sét. Đánh giá các rủi ro sức khỏe của người dân khi tiêu thụ gạo hàng ngày được thể hiện thông qua các chi số rủi ro không ung thư (HI) của các nguyên tố $\mathrm{As}, \mathrm{Cd}, \mathrm{Pb}, \mathrm{Co}, \mathrm{Cu}, \mathrm{Mn}, \mathrm{Mo}$, và Ni; cùng với chi số rủi ro ung thư của As và Pb ( $\Sigma I L C R)$. Tất cả các mẫu gạo được phân tích vượt quá chi số an toàn $H I<1$. 81\% của các mẫu có chỉ số HI nằm trong khoảng $1.4<H I<$ 5 và 18\% các mẫu trong $5<H I<8.4$, mặc dù các mẫu đất tương ứng được kiểm tra đều khônghoặc rất it thể hiện sự ô nhiễm. Các nguyên tố $C d, A s, M n$, và Pb là những tác nhân quan trọng nhất gây ra các rủi ro không ung thư cho những người tiêu thụ gạo. Rủi ro ung thư $\sum I L C R$ có giá trị trung bình $2.2 \times 10^{-3}$ và cao hơn đáng kể so với ngưỡng an toàn $10^{-4}-10^{-6}$, trong đó As là một tác nhân gây ung thư nổi bật. Những người sống ở khu vực sông Hồng và sông Hương đang đối mặt với sự phơi nhiễm As và Cd; trong khi đó người dân ở khu vực sông Mekông bị phơi nhiễm thêm Pb từ gạo.
\end{abstract}

Keywords: rice; paddy soil; element transfer; health risk; Vietnam

\section{Introduction}

Rice is the principal energy and protein supplying source for most of the Asian population in a daily basis. However, rice can be a prominent intake of harmful elements such as As, Cd, and Pb. Rahman and Hasegawa (2011) stated that, compared to other agricultural products, rice is the food with the highest content of As. High concentration of
As in rice and drinking water is recognized as one of the main reasons for serious chronic diseases affecting millions of inhabitants in Bangladesh and West Bengal, India (Bhattacharya et al., 2010; Abedin et al., 2002; Khan et al., 2009). Due to the uncomplicated uptake of $\mathrm{Cd}$ into rice plants, rice consumption can also cause illnesses (Rizwan et al. 2016). A 50\% of rice samples, collected in Cdpolluted paddy soils in Tak Province, Thailand, exceeded 


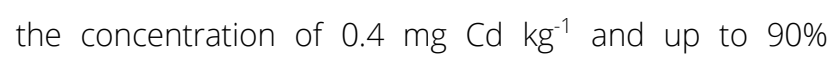
surpassed the permissible threshold of $0.2 \mathrm{mg} \mathrm{Cd} \mathrm{kg}^{-1}$ (Sriprachote et al. 2012; Simmons et al. 2005). Lead may also have a potential health risk in different rice-producing areas as recognized by Norton et al. (2014), Shraim (2017), and Fakhri et al. (2018). Chronic exposure to these elements causes deleterious health effects resulting in harmful impacts on heart, bones, skin, kidney, neurological disorders, and different cancer types (EFSA 2009, 2010; Smith et al. 2006; Kumarathilaka et al. 2018; Jaishankar et al. 2014).

Soils enriched with potentially toxic elements are often assumed to cause higher accumulation in plants. The growth and yield of rice plants can be negatively affected when exposed to high concentrations of trace metals (Marquez et al. 2018). Element concentrations in paddy soils are determined by their parent material, but also by anthropogenic contamination like mining and industrial operations, air pollution, agricultural practices (fertilizer and pesticides), and/or using contaminated wastewater for irrigation. However, the accumulation of an element in a plant depends on the plant species or cultivars, its concentration in soil phases, type of bonding and its concentration in interstitial solution. According to Xiao et al. (2017), the soil bioavailable concentration of Cd, Cr, and $\mathrm{Ni}$ and microbial activities have a major impact on their accumulation in rice grains. Some other external factors such as plant density, temperature, and light may also affect the element uptake but their effects are intricate and only poorly understood (Greger 2004). Interaction with Zn, $\mathrm{Fe}, \mathrm{Se}, \mathrm{Si}$, and liming, limits the uptake and translocation of Cd from root to shoot (Rizwan et al. 2016; Wan et al. 2018). According to Greger (2004), the fluid-transporting process from root to other plant parts is fostered by some factors: transpiration of water, root pressure, cation exchange at cell walls of the xylem vessel, formation of complexes with amino acid (for $\mathrm{Cu}$ ), with histidine and peptide (for $\mathrm{Ni}$ ), and chelates with organic acids (for Zn).

Vietnam is one of the world's largest rice producers (FAO 2018). The biggest granaries of the country are the Mekong River Delta in the south and the Red River Delta in the north where abundant water boosts irrigation. In addition, annual flooding events deliver fertile suspended material that settles in the riverine areas, including rice fields. As a result, parent material of paddy soils is mainly alluvial sediment, rich in organic matter. Some of the paddy soils in Vietnam are polluted by heavy metal(loid)s such as As, $\mathrm{Cd}, \mathrm{Cr}, \mathrm{Cu}, \mathrm{Pb}$, and $\mathrm{Zn}$ from industrial and mining activities leading to the contamination of rice grains (Huong et al. 2008; Phuong et al. 2010; Ha 2011; Vinh et al. 2012). However, most of the As contamination in paddy soils and rice grains comes from natural sources, strongly influenced by redox processes as described by Seyfferth et al. (2014) and Nguyen et al. (2020a, b). Around 11\% of the Mekong River soils and 92\% of Red River soils exceeded the Vietnamese As limit of $15 \mathrm{mg} \mathrm{kg}^{-1}$ for agricultural soils. Different soil conditions of these areas may be a reason for toxic element enrichments within the grains.

Similar investigations on the transfer of a broad variety of toxic elements into different rice plant parts are widely lacking in the literature. Understanding the influence of soil factors on element translocation, to and within the rice plant, is crucial to mitigate their uptake and protect human health. For Vietnam, as an important rice producing, consuming and exporting country, there are some information on the daily risk exposure to toxic metal(loid) intake by eating rice (Nguyen et al. 2020a, b). However, a corresponding chronic risk assessment for the population is still missing.

The goals of this research are: 1) to evaluate the translocation of a wide range of elements from paddy soils into the rice plant parts of under the influence of soil parameters such as $\mathrm{pH}$, organic material, Al-, Fe-, and Mnoxides/hydroxides; 2) to characterize the element concentration in the differing parts of rice plants (shoot, husk, grains); 3) to get information on long-term cancer and non-cancer health risks from rice consumption in Vietnam.

\section{Materials and methods}

\subsection{Sampling, digestion, analysis and quality control}

Rice plants and their corresponding soil samples were collected along three river systems in Vietnam including the Red River Delta in the north (19 sites), the Huong River in the center (4 sites), and the Mekong River Delta in the south (78 sites). The sample locations are shown in Fig. 1 (coordinates of the sampling sites are listed in Table S2 in the supplementary material). All samples were taken within 10 days before harvesting time. The 23 rice plant samples of the Red River and Huong River areas were separated into shoot (stalk and leaves combined), husk, and unpolished rice grain. Roots and stubbles were left in the fields. The 78 rice samples of the Mekong River area were split into husks and grains. The soil samples were taken within the root zone (a depth of $10 \mathrm{~cm}$ ). The analysis process was executed in the laboratory of the Geoscience Center of Göttingen University, Germany. 


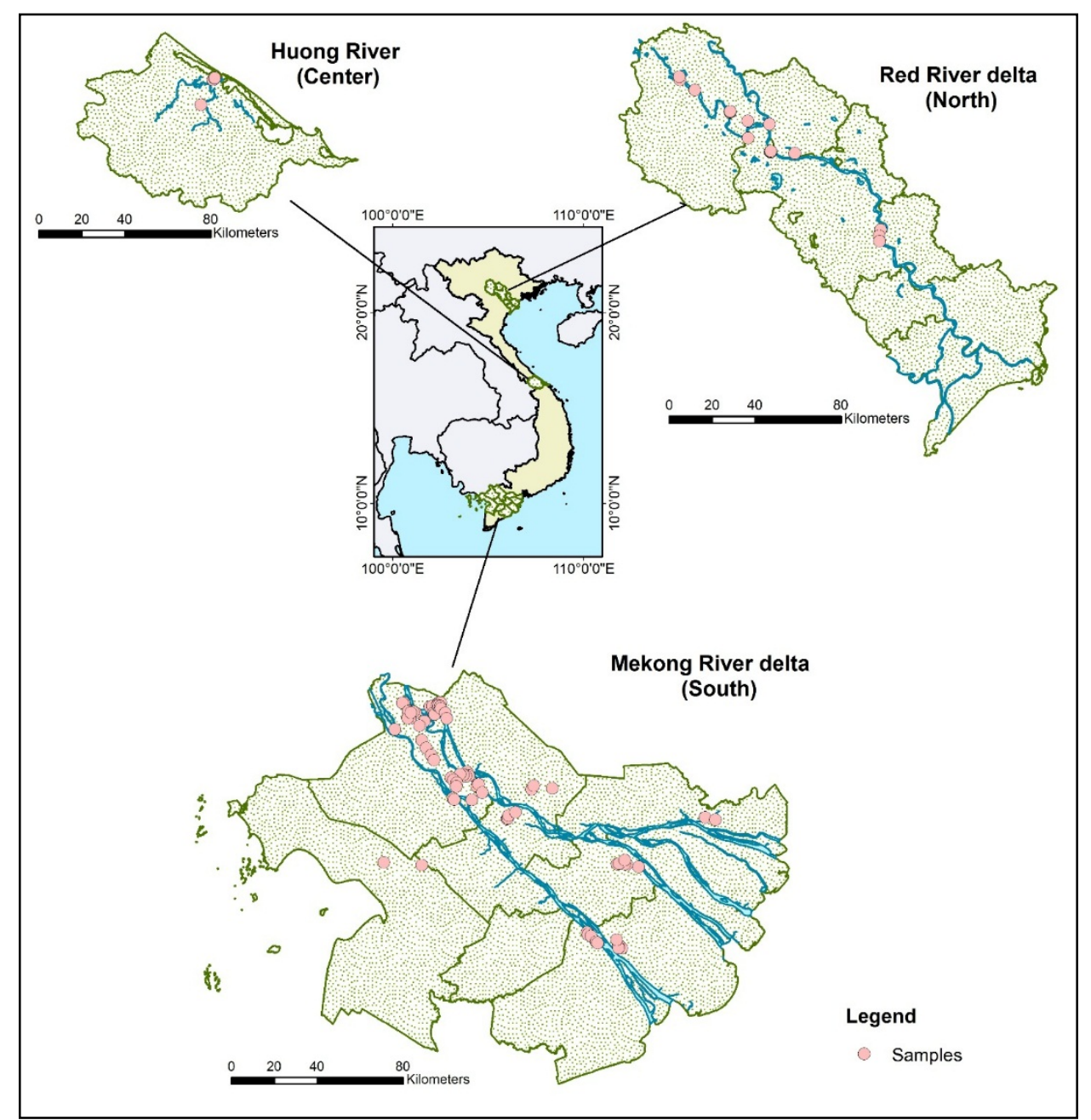

Figure 1. Sample locations in the three investigated river areas in Vietnam

The plant samples were dried at $60{ }^{\circ} \mathrm{C}$ and the soil samples at $105^{\circ} \mathrm{C}$. All samples were pulverized into grain sizes $<63$ $\mu \mathrm{m}$ by a Fritsch ${ }^{\odot}$ agate ball mill before analysis. Soils' $\mathrm{pH}$ values were determined in a 1:2.5 (w/v) ratio of air-dried unground soils to $0.01 \mathrm{M} \mathrm{CaCl}_{2}$ solution by using the glass electrode ProfiLine $\mathrm{pH} / \mathrm{mV}$-Meter 197.

The Loss on Ignition (LOI), representative for organic matter and structural water in the soil samples, was determined as the percentage weight loss after heating the samples to $530^{\circ} \mathrm{C}$ for 24 hours. The milled plant and soil samples were completely digested in a mixture of ultrapure concentrated acids $\mathrm{HNO}_{3}$ (65\%), $\mathrm{HF}(40 \%)$ and $\mathrm{HClO}_{4}(72 \%)$ in closed ultra clean PTFE vessels (PicoTrace ${ }^{\circ}$, Göttingen, Acid Sample Digestion System DAS 30). For the soil samples, about $1 \mathrm{ml}$ of $37 \% \mathrm{HCl}$ was added in the last step of the soil digestion procedure. The clear digestion solutions were then measured by ICP-OES (Inductively Coupled Plasma - Optical Emission Spectrometry) Agilent 5100 VDV and by ICP-MS (Inductively Coupled Plasma Mass Spectrometry) Thermo Scientific iCAP Q to get the total element concentrations.

\subsection{Exposure and long-term health risk calculations for rice consumption}

The chronic risk exposure from rice consumption affecting human health can be evaluated on the basis of indices of Lifetime Cancer Risk and of Lifetime Non-cancer Risk (Järup, 2003; Mulware, 2013). These indices are based on the Chronic Daily Intake (CDI) in mg per kg body weight per day (USEPA 1989) which can be determined as follows:

$$
C D I=(C F \times I R \times E F \times E D) /(B W \times A T)
$$

where CF is the harmful element concentration in rice (mg $\left.\mathrm{kg}^{-1}\right) ; I R$ is the average daily rice consumption of $0.398 \mathrm{~kg}$ day $^{-1}$ for Vietnamese adults (Nguyen et al. 2020); EF is the exposure frequency (365 days year ${ }^{-1}$ ); $E D$ is the exposure duration (70 years); $B W$ is the Vietnamese average body weight (b.w.) of $52 \mathrm{~kg}$ for an adult (Nguyen et al. 2020); AT is the average period of exposure days to hazardous element intake.

\subsubsection{Chronic non-cancer risks}

The chronic non-cancer risk approach is used to evaluate non-carcinogenic health effect of harmful elements from different sources. For rice, $\mathrm{As}, \mathrm{Cd}, \mathrm{Pb}, \mathrm{Mn}, \mathrm{Co}, \mathrm{Ni}, \mathrm{Cu}$, and Mo are considered as the most critical and potentially harmful elements causing adverse health effects. The 
Target Hazard Quotient (THQ) describes the exposure to an element and can be reckoned as follows:

$$
T H Q=C D / / R f D
$$

RfD is the chronic Reference Dose in $\mathrm{mg} \mathrm{kg}^{-1}$ b.w. day-1 of a harmful element and represents the maximum permissible element amount taken up from all sources (food, water, air etc.). The RfD values of elements for this paper are taken from previous research (Nguyen et al. 2020a, b).

The Chronic Hazard Index (H/) for non-cancer factors is the sum of the THQ for each relevant element and represents the total non-carcinogenic hazard attributable to exposure:

$$
H I=\sum_{n=1}^{\infty} T H Q
$$

At $\mathrm{HI} \geq 1$, potential health effects should be concerned even if the exposure for every single element is below its RfD (USEPA 1989). Nordberg et al. (2015a) noticed that the $\mathrm{HI}$-approach is simple but limited in its scope because it may either under- or over-estimate the risk from multiple chemical exposures.

\subsubsection{Chronic cancer risks}

Incremental Lifetime Cancer Risk (ILCR) is an index to estimate the incremental probability of an individual cancer progression over a lifetime (USEPA 1989). The ILCR of a harmful substance is computed as follows:

$$
I L C R=C D I \times S F
$$

where SF is the Slope Factor. It represents an upper estimate of increased cancer risk from a lifetime exposure to a carcinogenic substance by ingestion, inhalation or dermal contact in [mg / (kg b.w. day)] $]^{-1}$ (USEPA 1989). The three elements $\mathrm{As}, \mathrm{Cd}$, and $\mathrm{Pb}$ are considered as key carcinogenic risk factors for low dose element intakes. However, there is insufficient information about the slope factor of oral Cd intake, therefore, Cd was excluded. In this study, the ILCR of As and $\mathrm{Pb}$ are estimated for eating unpolished rice with slope factors $S F_{A S}=1.5$ and $S F_{P b}=$ 0.0085 [mg / (kg b.w. day)] $]^{-1}$ (OEHHA 2011).

Cumulative cancer risk $\left(\sum I L C R\right)$ is the sum of single lifetime cancer risks, which are restricted to the carcinogens As and $\mathrm{Pb}$ :

$$
\sum I L C R=I L C R_{A S}+I L C R_{P b}
$$

USEPA (1989), proposed a healthy safe level where \&ILCR is below $10^{-6}$. The acceptable suggested level falls in the range from $10^{-6}$ to $10^{-4}$.

\section{Results and discussion}

\subsection{Element distribution in parts of rice plants}

After being taken up, primarily by the root surface, ions are translocated by the xylem sap to the different plant parts. During the transport, many elements are enriched at cell walls (Greger 2004; Meharg and Zhao 2012). In general, the element transferability to plant parts depends on element species, plant genotypes/cultivars, and external factors. The translocation of elements in the plant takes place by the phloem and/or xylem sap. Essential elements fulfil different biological functions such as osmoregulation. The water and nutrient mass flow within the plant is driven by stomatal aperture, energy transfer, membrane permeability and electrochemical potentials. Furthermore, some of the elements serve as cell wall and membrane stabilizers and are necessary constituents of amino and nucleic acids, proteins, enzymes, coenzymes, and chlorophyll (Marschner 2012).

The elements $\mathrm{Ba}, \mathrm{Na}, \mathrm{Ca}, \mathrm{Mn}, \mathrm{Pb}, \mathrm{Co}, \mathrm{As}, \mathrm{K}, \mathrm{Cd}, \mathrm{Fe}, \mathrm{Ni}, \mathrm{Mg}$, $\mathrm{Zn}$, and $\mathrm{S}$ are more concentrated in shoot than in unpolished grains (Sh/Gr 84 to 2). Meanwhile, the Cu and Mo concentrations in shoot are approximate to those in unpolished grain. Especially, the $P$ concentration is enriched threefold in unpolished grains in comparison to shoot. The concentration of most elements (except $\mathrm{Ni}$ and $\mathrm{P}$ ) in shoot is higher than that in husk, especially for $\mathrm{Na}, \mathrm{Cd}$, $\mathrm{Mg}$, and $\mathrm{K}$. Most elements show higher concentrations in husk compared to those in grain, except for $\mathrm{Cu}, \mathrm{Cd}, \mathrm{S}, \mathrm{Zn}$, $\mathrm{P}, \mathrm{Mo}$, and $\mathrm{Mg}$. Preferential transfer of some elements to grains may be explained by ion charges or the formation of organic complexes (Marschner 2012). The negative ions phosphate, molybdate and sulfate are repelled by the negatively charged cell walls allowing the more distant transport to the grains. Elements such as Cu, Zn, Mg, Ni and presumably some other metals may be transported within the plant as soluble organic complexes.

Following a general trend, most element concentrations decrease in the order: shoot > husk > grain; Cd, Mg, Zn, S, $\mathrm{Cu}$, and Mo concentrations in the order: shoot $>$ grain $>$ husk, and P concentration in the order: grain > shoot $>$ husk. Meng et al. (2018) found comparable results for the cd distribution in rice plant parts.

On average, the masses portions of the plant parts to the whole aboveground plants are 0.42 of shoot, 0.46 of grain, and 0.12 of husk (Table 1$)$. The relative mass portions of elements in different parts are shown in Fig. 2. A large load of most elements is stored in the shoot, holding more than $50 \%$ of the total element uptake. In contrast, $50 \%-80 \%$ of the $\mathrm{P}, \mathrm{Mo}, \mathrm{Ni}$, and $\mathrm{Cu}$ uptake is accumulated in the grain. The storage of elements in husk is below 10\% except for $\mathrm{Pb}, \mathrm{Bi}$, and $\mathrm{Sb}$. 


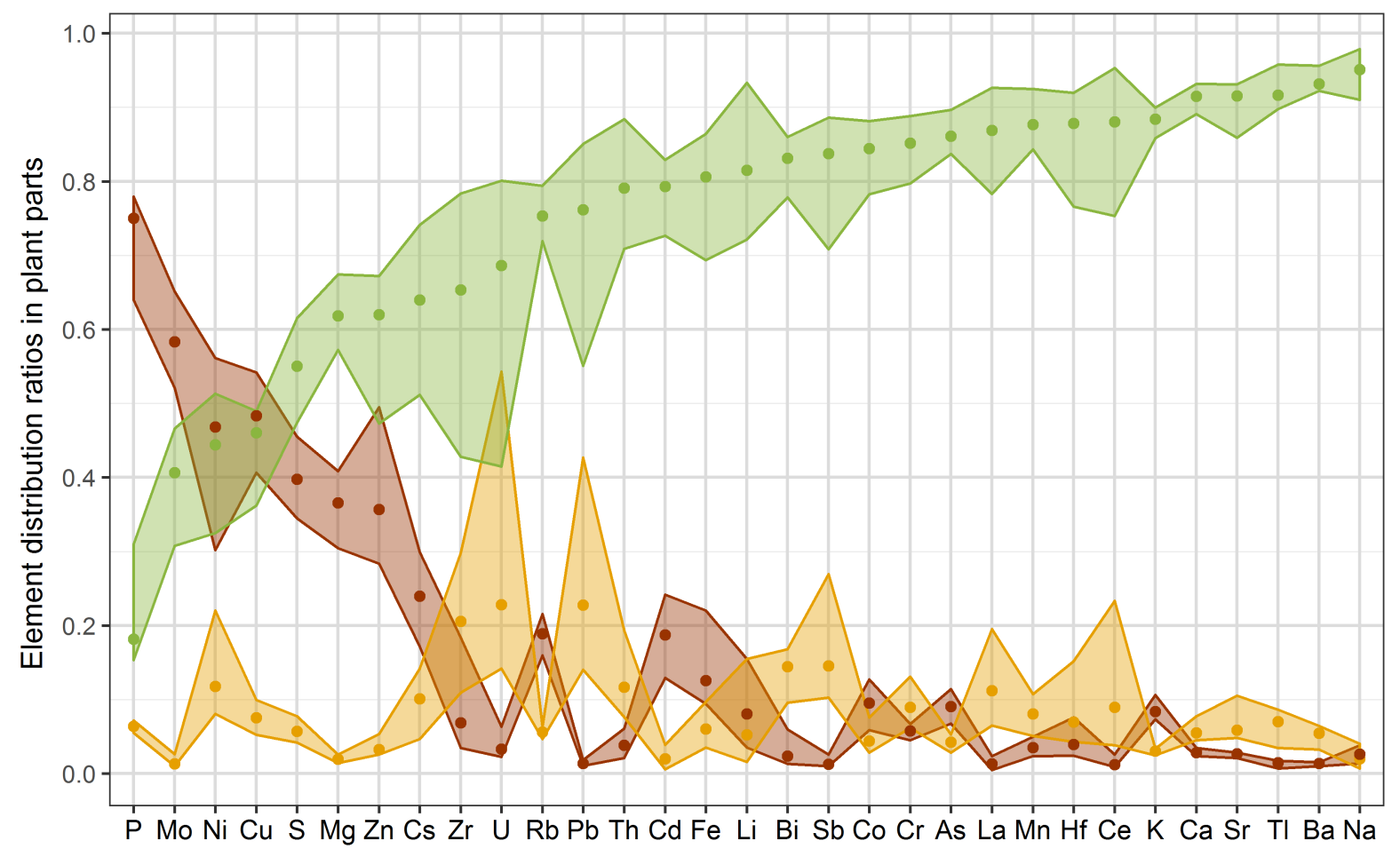

- Grain $\bullet$ Husk $\bullet$ Shoot

Figure 2. Mass portions of elements in plant parts in relation to the aboveground rice plant for 23 samples in northern and central Vietnam. The sum of the portions of each element in grain, husk and shoot equals 1 . Dots represent median values; the colored areas cover the range of the $1^{\text {st }}$ to $3^{\text {rd }}$ quartile portion for each element.

There is a great difference among mean concentrations of potentially harmful elements in soils and related rice plant parts among other regions in Asia as compiled in Table 2. Arsenic concentrations in Japanese and Vietnamese soils are similar, but two times lower in soils from India, Malaysia, Thailand, and China. However, husk and grain samples from India and Malaysia contain 2 - 3 times more As. This can be explained by the very high As concentration, up to $700 \mu \mathrm{g} \mathrm{L}^{-1}$, in the irrigation water (Biswas et al. 2014). Surprisingly, the As concentrations in shoots in India are about 3 times lower than those in China and Vietnam. The $\mathrm{Cd}$ concentrations in soils and grains in China, Japan, and Vietnam are remarkably higher than those in other countries. Concentrations of other potentially harmful elements are approximate among rice grains in China, Japan, and Vietnam. Rice grains in India and Malaysia have high contents of As, $\mathrm{Cr}$ and $\mathrm{Pb}$. Korea shows heavy metal concentrations in soils remarkably low compared to China, Japan, and Vietnam. Nearly all elements within the different areas show decreasing concentrations in the order soil > shoot > husk > grain. 


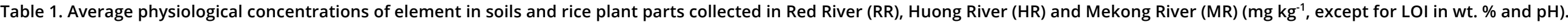
Ratio represents the mass ratio of shoot, husk, or unpolished grain to the whole aboveground plant

\begin{tabular}{|c|c|c|c|c|c|c|c|c|c|c|c|c|c|c|c|c|}
\hline \multirow{2}{*}{ Element } & \multicolumn{4}{|c|}{ Soil $(n=101)$} & \multicolumn{4}{|c|}{ Shoot $(n=23)$} & \multicolumn{4}{|c|}{ Husk $(n=101)$} & \multicolumn{4}{|c|}{ Grain $(n=101)$} \\
\hline & $\mathrm{RR}$ & $\mathrm{HR}$ & MR & Mean & RR & $\mathrm{HR}$ & MR & Mean & RR & $\mathrm{HR}$ & MR & $\overline{\text { Mean }}$ & $\mathrm{RR}$ & $\mathrm{HR}$ & MR & Mean \\
\hline Ratio & - & - & - & - & 0.41 & 0.47 & - & $\overline{0.42}$ & 0.12 & 0.11 & 0.12 & 0.12 & 0.47 & 0.43 & 0.46 & 0.46 \\
\hline $\mathrm{pH}$ & 6.2 & 4.4 & 5.0 & 5.2 & - & - & - & - & - & - & - & - & - & - & - & - \\
\hline LOI & 6.5 & 6.4 & 10.3 & 9.3 & - & - & - & - & - & - & - & - & - & - & - & \\
\hline Al & 75850 & 74854 & 87130 & 84522 & $<4$ & $<4$ & - & $<4$ & $<4$ & $<4$ & $<4$ & $<6$ & $<4$ & $<4$ & $<4$ & $<4$ \\
\hline $\mathrm{Ca}$ & 5689 & 2180 & 3725 & 4033 & 5219 & 3915 & - & 4992 & 1099 & 1388 & 749 & 840 & 134 & 139 & 87 & 98 \\
\hline $\mathrm{Fe}$ & 44221 & 34523 & 34773 & 36541 & 70 & 163 & - & 86 & 23.8 & 28.6 & 20.0 & 21 & 10.8 & 12.9 & 10.3 & 10.5 \\
\hline $\mathrm{K}$ & 20081 & 19786 & 19680 & 19760 & 35711 & 22842 & - & 33473 & 3878 & 5184 & 4010 & 4032 & 2897 & 2945 & 2595 & 2666 \\
\hline $\mathrm{Mg}$ & 8142 & 5772 & 6460 & 6750 & 2671 & 3013 & - & 2731 & 311 & 415 & 324 & 325 & 1384 & 1240 & 1290 & 1305 \\
\hline $\mathrm{Mn}$ & 526 & 254 & 304 & 344 & 696 & 848 & - & 723 & 256 & 252 & 177 & 195 & 22 & 24 & 21 & 21 \\
\hline $\mathrm{Na}$ & 5295 & 2991 & 4587 & 4657 & 346 & 541 & - & 380 & 20.1 & 8.6 & 52.5 & 44.7 & 4.2 & 5.5 & 7.6 & 6.9 \\
\hline$P$ & 865 & 487 & 780 & 785 & 1139 & 1493 & - & 1200 & 1308 & 1104 & 1411 & 1380 & 3545 & 3235 & 3269 & 3319 \\
\hline$S$ & 651 & 516 & 930 & 861 & 1635 & 2352 & - & 1760 & 690 & 554 & 625 & 634 & 1089 & 1051 & 880 & 926 \\
\hline $\mathrm{Ti}$ & 4854 & 4856 & 4808 & 4819 & 0 & 0 & - & 0 & 0 & 0 & 0 & 0.0 & 0 & 0 & 0 & 0 \\
\hline As & 22.5 & 13.6 & 12.6 & 14.8 & 2.7 & 3.2 & - & 2.82 & 0.41 & 0.78 & 0.30 & 0.34 & 0.21 & 0.27 & 0.18 & 0.19 \\
\hline $\mathrm{Ba}$ & 417 & 460 & 394 & 402 & 93 & 125 & - & 99 & 19.2 & 21.5 & 7.1 & 10.0 & 1.24 & 1.51 & 0.51 & 0.69 \\
\hline $\mathrm{Bi}$ & 0.88 & 0.56 & 0.40 & 0.51 & 0.010 & 0.008 & - & 0.009 & 0.0058 & 0.0035 & 0.0006 & 0.0017 & $<0.0004$ & 0.0017 & $<0.0004$ & $<0.0004$ \\
\hline $\mathrm{Cd}$ & 0.37 & 0.25 & 0.27 & 0.29 & 0.44 & 0.45 & - & 0.44 & 0.103 & 0.155 & 0.028 & 0.047 & 0.120 & 0.085 & 0.037 & 0.055 \\
\hline $\mathrm{Ce}$ & 90 & 83 & 81 & 83 & 0.123 & 0.202 & & 0.137 & 0.0714 & 0.0537 & 0.0230 & 0.0333 & $<0.0009$ & 0.0058 & $<0.0007$ & $<0.001$ \\
\hline Co & 15.7 & 13.3 & 13.2 & 13.8 & 0.17 & 0.79 & - & 0.28 & 0.063 & 0.126 & 0.045 & 0.052 & 0.016 & 0.083 & 0.025 & 0.026 \\
\hline $\mathrm{Cr}$ & 69 & 39 & 94 & 86 & 0.97 & 0.71 & - & 0.92 & 0.38 & 0.39 & 0.17 & 0.22 & $<0.1$ & $<0.1$ & $<0.1$ & $<0.24$ \\
\hline $\mathrm{Cu}$ & 48 & 27 & 30 & 34 & 3.52 & 3.51 & - & 3.52 & 2.23 & 2.21 & 1.99 & 2.04 & 3.35 & 3.58 & 3.26 & 3.29 \\
\hline Mo & 0.98 & 1.07 & 0.94 & 0.95 & 0.52 & 0.71 & - & 0.55 & 0.10 & 0.06 & 0.17 & 0.16 & 0.64 & 0.69 & 0.41 & 0.47 \\
\hline $\mathrm{Ni}$ & 39.9 & 28.5 & 36.3 & 36.4 & 0.37 & 0.85 & - & 0.45 & 0.58 & 0.44 & 0.42 & 0.45 & 0.36 & 0.95 & 0.30 & 0.34 \\
\hline $\mathrm{Pb}$ & 50.5 & 29.7 & 28.6 & 33.5 & 0.73 & 0.13 & - & 0.63 & 0.90 & 0.74 & 0.44 & 0.54 & $<0.02$ & $<0.02$ & 0.17 & 0.17 \\
\hline $\mathrm{Sb}$ & 2.01 & 1.58 & 2.06 & 2.03 & 0.033 & 0.008 & - & 0.029 & 0.0234 & 0.0095 & 0.0028 & 0.0070 & $<0.0006$ & $<0.0006$ & $<0.0006$ & $<0.0007$ \\
\hline Sn & 4.81 & 4.56 & 4.15 & 4.32 & $<1.16$ & $<0.06$ & - & 0.94 & $<0.69$ & $<0.06$ & $<0.32$ & $<0.38$ & $<0.06$ & $<0.06$ & $<0.16$ & $<0.14$ \\
\hline U & 3.74 & 4.53 & 4.45 & 4.30 & 0.0096 & 0.0042 & - & 0.0087 & 0.0062 & 0.0032 & 0.0025 & 0.0032 & $<0.0001$ & 0.0006 & $<0.0001$ & $<0.0001$ \\
\hline $\mathrm{Zn}$ & 110 & 83 & 90 & 94 & 40.1 & 62.6 & - & 44 & 11.5 & 9.5 & 15.9 & 14.8 & 23.1 & 26.9 & 19.6 & 20.5 \\
\hline
\end{tabular}


Table 2. Mean concentrations of selected elements in soils and rice plant parts $\left(\mathrm{mg} \mathrm{kg}^{-1}\right)$ in Vietnam compared to other Asian countries

\begin{tabular}{|c|c|c|c|c|c|c|c|c|c|c|c|}
\hline & Country & Area & $\mathrm{n}$ & As & $\mathrm{Cd}$ & $\mathrm{Cr}$ & $\mathrm{Cu}$ & $\mathrm{Mn}$ & $\mathrm{Ni}$ & $\mathrm{Pb}$ & $\mathrm{Zn}$ \\
\hline \multirow[t]{7}{*}{ Soil } & India & West Bengal & 188 & 7.3 & - & - & - & - & - & - & - \\
\hline & Malaysia & Whole country & 16 & 8.0 & 0.07 & 27 & 9 & - & 12 & 28 & 28 \\
\hline & Thailand & Whole country & 108 & 6.4 & 0.04 & 25 & 12 & - & 13 & 20 & 24 \\
\hline & China & Yangtze River Delta & 137 & 7.3 & 0.36 & 73 & 41 & - & - & 32 & 117 \\
\hline & Korea & Whole country & 82 & 4.4 & 0.25 & - & 13 & - & 14 & 21 & 54 \\
\hline & Japan & Whole country & 111 & * & 0.45 & - & 20 & - & - & - & 96 \\
\hline & Vietnam & This work & 101 & 14.4 & 0.29 & 87 & 33 & 343 & 36 & 33 & 93 \\
\hline \multirow[t]{3}{*}{ Shoot } & India & West Bengal & 248 & 0.91 & - & - & - & - & - & - & - \\
\hline & China & Yangtze River Delta & 137 & 3.51 & 0.34 & 0.83 & 26 & - & - & 1.97 & 63.8 \\
\hline & Vietnam & This work & 101 & 2.82 & 0.44 & 0.92 & 3.5 & 723 & 0.45 & 0.63 & 44.0 \\
\hline \multirow[t]{2}{*}{ Husk } & India & West Bengal & 248 & 0.74 & - & - & - & - & - & - & - \\
\hline & Vietnam & This work & 101 & 0.34 & 0.05 & 0.22 & 2.0 & 195 & 0.45 & 0.54 & 14.8 \\
\hline \multirow[t]{7}{*}{ Grain } & India & West Bengal & $248 / 5$ & 0.28 & - & - & - & - & - & - & - \\
\hline & Malaysia & Whole country & 16 & 1.27 & 0.01 & 0.37 & 1.9 & - & 1.1 & 0.24 & 42 \\
\hline & Thailand & Whole country & 108 & $<1$ & 0.05 & 0.7 & 2 & - & 1.7 & 0.11 & 22.8 \\
\hline & China & Yangtze River Delta & 137 & 0.13 & 0.06 & 0.19 & 5.2 & - & - & 0.10 & 22.8 \\
\hline & Korea & Whole country & 82 & 0.15 & 0.02 & - & 4.3 & - & 0.35 & 0.11 & 22.6 \\
\hline & Japan & Whole country & 111 & * & 0.05 & - & 3.3 & - & - & - & 15.5 \\
\hline & Vietnam & This work & 101 & 0.19 & 0.06 & $<0.24$ & 3.3 & 21 & 0.42 & 0.17 & 20.5 \\
\hline
\end{tabular}

India: Biswas et al. (2014); Malaysia: Zarcinas et al. (2004a); Thailand: Zarcinas et al. (2004b); China: Mao et al. (2019); Korea: Kunhikrishnan et al. (2015); Japan: Herawati et al. (2000) for Cd, Cu, and Zn ( $n=111)$; * Kuramata et al. (2010): on soils containing $1.4 \mathrm{mg} \mathrm{As} \mathrm{kg}^{-1}$, the mean As concentration in 10 grain samples of rice cultivars is $0.14 \mathrm{mg} \mathrm{kg}^{-1}$; on soils containing $8 \mathrm{mg} \mathrm{As} \mathrm{kg}^{-1}$, the corresponding mean As content in 10 grain samples is $2.4 \mathrm{mg} \mathrm{kg}^{-1}$.

\subsection{Impact of soil parameter on element transfer}

The influence of the soil parameters $\mathrm{pH}, \mathrm{LOI}, \mathrm{Al}, \mathrm{Fe}$, and $\mathrm{Mn}$ on the transfer of elements was evaluated and the results are displayed in Table 3. These influences can be explained by the fact that each soil parameter has a different impact on element availability. Thus, the element concentration in the plant reflects the combined effects of all soil parameters as mentioned in literature (Blume et al. 2016). Some effects of soil parameters on the transfer of elements are summarized as follows:

- $\quad$ The negative correlation trends of the transfer of elements $\mathrm{Ca}, \mathrm{Mn}, \mathrm{P}, \mathrm{Cd}, \mathrm{Co}, \mathrm{Cu}$, and $\mathrm{Ni}$ with soil $\mathrm{pH}$ value may be explained by higher plant-available element concentration in soil solution at lower $\mathrm{pH}$ value. In an acidic environment, $\mathrm{H}^{+}$ions can replace sorbed cations at the surfaces of soil phases and release them into solution. This facilitates the element uptake by the plant.

- Opposite to cations, Mo shows an increased uptake trend towards higher $\mathrm{pH}$-value. Under reducing conditions, Mo is able to form complexes with organic matter, presumably with sulphur groups. Increasing soil pH-values lead to more biological destruction of organic matter, releasing Mo into the soil solution.
- $\quad$ The transfer of $\mathrm{Cr}$ and Mo are negatively correlated with soil Fe and Al. Chromium and Mo are less sorbed at low Fe and Al concentrations in soil, facilitating their plant uptake.

- The positive correlations among the transfers of As, $\mathrm{Bi}$, and Sb suggest similar availability trends in the soil and comparable uptake mechanisms by the plant.

- $\quad$ The transfer of $\mathrm{Mg}, \mathrm{S}, \mathrm{As}, \mathrm{Bi}, \mathrm{Cr}, \mathrm{Mo}, \mathrm{Ni}, \mathrm{Sb}$, and $\mathrm{Zn}$ show negative trends with the soil $\mathrm{Fe}$ and $\mathrm{Al}$ concentrations. The sorption of these elements on Fe-oxides/hydroxides or clay minerals leads into a decrease of their bioavailable concentrations in soil solution, hence, reducing their concentrations in rice plants.

- $\quad$ The OM content influences positively the transfer of As. The OM may form soluble As organic complexes, facilitating the As transport into the plant. In contrast, increasing OM content leads to decreasing transfer of $\mathrm{S}, \mathrm{Cr}, \mathrm{Cu}$, and Mo. While Sulphur is a compound of the OM, other elements may be sorbed. Under oxidizing conditions and/or at higher $\mathrm{pH}$-value, organic compounds are degraded and release these elements into solution facilitating their plant uptake. 
Table 3. Influences of soil parameters and soil element concentrations on transportability of elements to aboveground rice plants from the Red River and Huong River areas, listed in decreasing order of importance

\begin{tabular}{llll}
\hline Element & Soil factors & & Element \\
\cline { 2 - 3 } $\mathrm{Ca}$ & $-\mathrm{Ca},-\mathrm{pH}>-\mathrm{Mn}>+\mathrm{Al}$ & $\mathrm{Cs}$ & $-\mathrm{Cs}$ \\
$\mathrm{Mg}$ & $-\mathrm{Mg},-\mathrm{Fe}>-\mathrm{Mn}$ & $\mathrm{Cu}$ & $-\mathrm{Cu}>-\mathrm{LOI}>-\mathrm{pH}$ \\
$\mathrm{Mn}$ & $-\mathrm{Mn}>-\mathrm{pH}$ & $\mathrm{Mo}$ & $-\mathrm{Mo}>-\mathrm{Fe},-\mathrm{Al},-\mathrm{LOI},+\mathrm{pH}$ \\
$\mathrm{Na}$ & $-\mathrm{Na},+\mathrm{Fe}>+\mathrm{LOI}>+\mathrm{Al}$ & $\mathrm{Ni}$ & $-\mathrm{Ni}>-\mathrm{Mn},-\mathrm{pH},-\mathrm{Fe}$ \\
$\mathrm{P}$ & $-\mathrm{P}>-\mathrm{pH}>-\mathrm{Mn}$ & $\mathrm{Pb}$ & $-\mathrm{Pb}$ \\
$\mathrm{S}$ & $-\mathrm{LOI},-\mathrm{S}>-\mathrm{Al},-\mathrm{Fe}$ & $\mathrm{Rb}$ & $-\mathrm{Rb}>-\mathrm{Fe},-\mathrm{Al}$ \\
$\mathrm{As}$ & $-\mathrm{As}>+\mathrm{LOl},-\mathrm{Fe}$, & $\mathrm{Sb}$ & $-\mathrm{Sb}>+\mathrm{pH},-\mathrm{Fe}$ \\
$\mathrm{Bi}$ & $-\mathrm{Bi}>-\mathrm{Fe}$ & $\mathrm{Sr}$ & $-\mathrm{Sr}>-\mathrm{Fe}>-\mathrm{pH}$ \\
$\mathrm{Cd}$ & $-\mathrm{pH}>-\mathrm{Mn}$ & $\mathrm{Tl}$ & $-\mathrm{pH},-\mathrm{Mn}$ \\
$\mathrm{Co}$ & $-\mathrm{pH},-\mathrm{Mn}$ & $\mathrm{Zn}$ & $-\mathrm{Fe},-\mathrm{Zn}$ \\
$\mathrm{Cr}$ & $-\mathrm{Cr},-\mathrm{Fe}>-\mathrm{Al},-\mathrm{LOI}$ & &
\end{tabular}

+ positive correlation trends (mostly linear); - negative correlation trends (mostly exponentially decreasing)

$\mathrm{Fe}, \mathrm{K}, \mathrm{Ba}, \mathrm{Li}, \mathrm{Sn}$, and U show no visible correlation with soil factors or their soil concentration.

\subsection{Health risk assessment}

Potentially harmful elements such as $\mathrm{As}, \mathrm{Cd}, \mathrm{Pb}, \mathrm{Co}, \mathrm{Cu}$, $\mathrm{Mn}, \mathrm{Mo}$, and $\mathrm{Ni}$ were selected to estimate the non-cancer risk by means of Target Hazard Quotients (THQ), for single elements, and chronic cumulative Hazard Index (HI) for all selected elements (USEPA 1989; Nordberg et al. 2015a).
Elements with implicit carcinogenic risk like As and $\mathrm{Pb}$ are evaluated by means of Incremental Lifetime Cancer Risk (ILCR) and Cumulative Cancer Risk ( ILCR). Statistics on the exposure risk of each element and total health risks for the three river areas are compiled in Table 4. The HI and $\sum$ ILCR for the samples of the three river areas are plotted in Fig. 3.

Table 4. Indexes for health risk assessment for harmful elements including non-cancer risk and cancer risk

\begin{tabular}{|c|c|c|c|c|c|c|c|c|c|c|c|c|}
\hline Index & Area & Statistics & As & $\mathrm{Pb}$ & $\mathrm{Cd}$ & Co & $\mathrm{Cu}$ & $\mathrm{Mn}$ & Mo & $\mathrm{Ni}$ & $\mathrm{HI}$ & $\sum I L C R$ \\
\hline $\mathrm{RfD}(\mathrm{x} 1 \mathrm{C}$ & & & 2 & 1.5 & 1.5 & 0.35 & 200 & 200 & 40 & 20 & - & 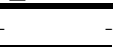 \\
\hline CDI & Red & Min-Max & $0.8-2.6$ & $<0.2$ & $0.02-7.4$ & $0.03-0.24$ & $5.5-65$ & $88-348$ & $1.4-9.9$ & $0.2-7.8$ & - & 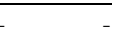 \\
\hline \multirow[t]{6}{*}{$\left(\times 10^{-3}\right)$} & & Mean & 1.6 & $<0.2$ & 0.92 & 0.12 & 26 & 170 & 4.9 & 2.8 & - & - \\
\hline & Huong & Min-Max & $1.0-2.6$ & $<0.2$ & $0.33-0.96$ & $0.48-1.02$ & $21-36$ & 163-202 & $3.7-7.0$ & $2.9-17$ & - & - \\
\hline & & Mean & 2.1 & $<0.2$ & 0.63 & 0.63 & 27 & 181 & 5.3 & 7.3 & - & - \\
\hline & Mekong & Min-Max & $0.6-4.3$ & $0.02-7.1$ & $0.06-0.88$ & $0.06-0.88$ & 8.4-78 & $101-219$ & $0.8-7.8$ & $0.2-23$ & - & - \\
\hline & & Mean & 1.4 & 1.3 & 0.19 & 0.19 & 25 & 158 & 3.2 & 3.1 & - & - \\
\hline & Mean & Mean & 1.5 & 1.0 & 0.42 & 0.20 & 25 & 161 & 3.6 & 3.2 & - & - \\
\hline \multirow[t]{7}{*}{ THQ } & Red & Min-Max & $0.41-1.3$ & $<0.1$ & $0.05-21$ & $0.02-0.16$ & $0.03-0.33$ & $0.44-1.74$ & $0.03-0.25$ & $0.01-039$ & $1.4-24$ & - \\
\hline & & Mean & 0.80 & $<0.1$ & 2.6 & 0.08 & 0.13 & 0.85 & 0.12 & 0.14 & 4.7 & - \\
\hline & Huong & Min-Max & $0.5-1.3$ & $<0.1$ & $0.93-2.7$ & $0.32-0.68$ & $0.11-0.18$ & $0.81-1.01$ & $0.09-0.18$ & $0.15-0.86$ & $3.7-6.1$ & - \\
\hline & & Mean & 1.04 & $<0.1$ & 1.86 & 0.42 & 0.14 & 0.91 & 0.13 & 0.37 & 4.9 & - \\
\hline & Mekong & Min-Max & $0.29-2.1$ & $0.1-4.7$ & $0.03-4.1$ & 0.04-0.59 & $0.04-0.39$ & $0.50-1.09$ & $0.02-0.20$ & $0.01-1.13$ & $1.6-8.4$ & - \\
\hline & & Mean & 0.70 & 0.87 & 0.81 & 0.13 & 0.12 & 0.79 & 0.08 & 0.15 & 3.7 & - \\
\hline & Mean & Mean & 0.73 & 0.69 & 1.19 & 0.13 & 0.13 & 0.81 & 0.09 & 0.16 & 3.9 & 9 \\
\hline ILCR & Red & Min-Max & $12-39$ & $<0.01$ & - & - & - & - & - & - & - & $-12-39$ \\
\hline \multirow[t]{6}{*}{$\left(\times 10^{-4}\right)$} & & Mean & 24 & $<0.01$ & - & - & - & - & - & - & - & 24 \\
\hline & Huong & Min-Max & $15-39$ & $<0.01$ & - & - & - & - & - & - & - & $-\quad 15-39$ \\
\hline & & Mean & 31 & $<0.01$ & - & - & - & - & - & - & - & 31 \\
\hline & Mekong & Min-Max & $9-64$ & $0.01-0.6$ & - & - & - & - & - & - & - & $9-64$ \\
\hline & & Mean & 21 & 0.1 & - & - & - & - & - & - & - & 21 \\
\hline & Mean & Mean & 22 & 0.09 & - & - & - & - & - & - & - & 22 \\
\hline$\overline{R f D:}$ & $\begin{array}{l}\text { Refere } \\
\text { day }^{1}\end{array}$ & $\begin{array}{l}\text { e Dose of } \\
\text { uyen et al }\end{array}$ & $\begin{array}{l}\text { ment repr } \\
\text { b); }\end{array}$ & resents its & त & IISSIOI & for da & UIA & 74 & ty & $\overline{m g g^{-1}}$ & b.w. \\
\hline CDI: & Chronic & Daily Intake & an elemen & $t$ from rice & consumptio & on in $\mathrm{mg} k \mathrm{~kg}$ & ${ }^{-1}$ b.w. day ${ }^{-1}$ & & & & & \\
\hline THQ: & Target H & azard Quoti & s; HI: chro & nic cumula & ative Hazard & Index for $n$ & on-cancer ri & & & & & \\
\hline ILCR: & Increm & tal Lifetim & cer Risk: & $\sum I L C R:$ Incr & mental Cur & mulative Ca & ncer Risk & & & & & \\
\hline
\end{tabular}

\subsubsection{Non-cancer risks}

Chronic cumulative Hazard Indexes $(\mathrm{HI})$ for the intake of the elements $\mathrm{As}, \mathrm{Cd}, \mathrm{Pb}, \mathrm{Co}, \mathrm{Cu}, \mathrm{Mn}, \mathrm{Mo}$, and $\mathrm{Ni}$ from rice consumption were calculated. All samples have $\mathrm{HI}$ values $\geq$ 1.4, surpassing the safe level of 1 as suggested by USEPA (1989). A 39\% of the samples show HI-values ranging between 1.4 and 3, 44\% ranges between 3 and 5, and 18\% ranges between 5 and 8.4. Rice consumption poses health hazards of concern with $\mathrm{HI}>5$ in $26 \%$ of the Red River samples, in 2 of 4 samples from the Huong River, and 14\% of the Mekong River samples. Cadmium, As, Pb, and Mn are the most prominent harmful elements by rice consumption and contribute in 64 - 97\% (average 86\%) to 
the HI-index. In some samples, the THQs of $\mathrm{Cd}, \mathrm{Pb}, \mathrm{As}$, and $\mathrm{Mn}$ are very high, reaching up to $21,4.7,2.1$, and 1.7 respectively. The elements $\mathrm{Ni}, \mathrm{Cu}, \mathrm{Co}$, and Mo cause a much lower risk. For lacking data, other sources for harmful element intake such as other food, drinking water or air pollution were not included in this study, but should be also considered to assess the real danger arising from these contaminants.

For arsenic, 3 of 4 samples from the Huong River, 26\% of the Red River samples and $14 \%$ of the Mekong River samples have $\mathrm{THQ}_{\mathrm{As}}>1$. On the average, As contributes in $22 \%$ to the $\mathrm{HI}$ value in the three river areas. For cadmium, 39\% of the Red River and 29\% and Mekong River samples show $\mathrm{THQ}_{\mathrm{cd}}>$ 1. Especially, samples HN10 and HN9, collected close to a brick manufactory, have $\mathrm{THQ}_{\mathrm{cd}}$ of 21 and 7 respectively. Cadmium contributes in 23\% on average to the total hazard index $(\mathrm{HI})$ in the three river areas. All of the Red River and Huong River grain samples have very low $\mathrm{Pb}$ concentrations $<0.02 \mathrm{mg} \mathrm{\textrm {kg } ^ { - 1 }}$ corresponding to $\mathrm{CDI}_{\mathrm{pb}}<0.2 \mathrm{mg} \mathrm{kg}^{-1}$ b.w. day ${ }^{-1}$ and $\mathrm{THQ} \mathrm{Pb}$ $<0.1$. Lead is responsible for less than $2 \%$ of the HI-value in these two river areas. In contrast, the Mekong River grain samples contain at least 10-times more $\mathrm{Pb}$ than the samples from the other river areas. Lead contributes in 3 69\% (average 21\%) to the total hazard risk in the Mekong River area. Manganese is usually not considered as a harmful element. In fact, on the average, Mn holds $24 \%$ of the $\mathrm{HI}$ values. Manganese surpasses THQ $=1$ in $10 \%$ of the samples, but $99 \%$ of the samples have $\mathrm{THQ}>0.5$.

\subsubsection{Cancer risk}

The index of Incremental Lifetime Cancer Risk (ILCR) for As and $\mathrm{Pb}$ from rice consumption, as well as the Cumulative Cancer Risk ( $\sum \mathrm{ILCR}$ ) is calculated and shown in Table 6 and Fig. 5. The ILCR depicts the probability of causing cancer, for example ILCR $10^{-4}$ indicates that 1 in 10,000 individuals develops cancer. All samples exceed the threshold of acceptable cancer risk which should range from $10^{-4}$ to $10^{-}$ ${ }^{6}$ according to USEPA (1989). In the $\sum$ ILCR $10^{-4}-10^{-3}$, health risk management should take action. The $\sum$ ILCR values fluctuate from $9 \times 10^{-4}$ to $64 \times 10^{-4}$ (average $22 \times 10^{-4}$ ), revealing a high level of cancer risk. The mean $\sum$ ILCR levels are $21 \times 10^{-4}$ of the Mekong River rice, $24 \times 10^{-4}$ of the Red River rice, and $31 \times 10^{-4}$ of the Huong River rice. The slightly greater risk of the Huong River samples might be due to the strongly acidic condition of the soils (Nguyen et al. 2020). Of these two elements, As contributes $96 \%$ to the IILCR while Pb only holds 4\%. Cadmium represents an important cancer risk factor for the Red River and the Huong River rice. However, the cancer risk of Cd is mainly by inhalation while the oral intake may be overlooked.
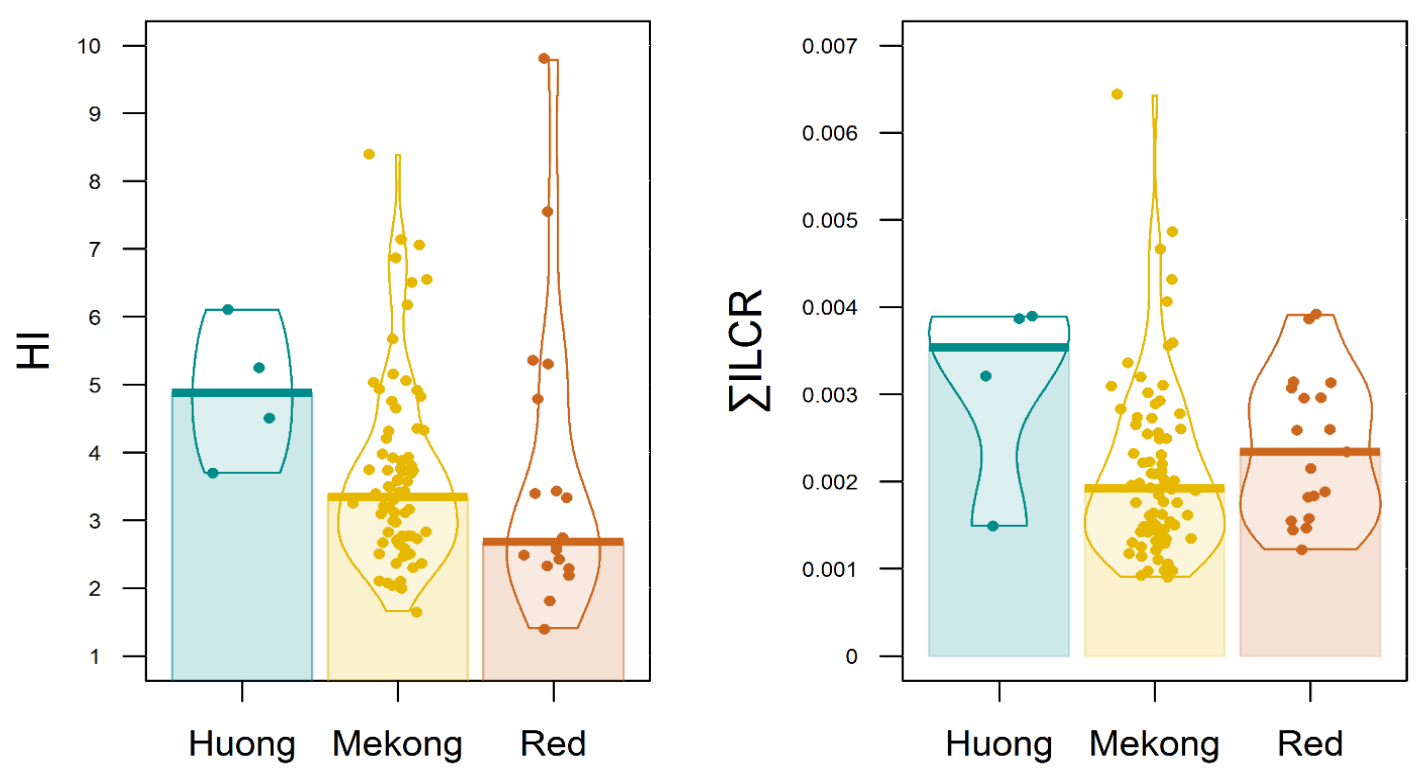

Figure 3. Target hazard index $(\mathrm{HI})$ for non-cancer risk from intake of $\mathrm{As}, \mathrm{Cd}, \mathrm{Pb}, \mathrm{Co}, \mathrm{Cu}, \mathrm{Mn}$, Mo, and $\mathrm{Ni}$ by rice consumption and cumulative carcinogenic risk ( $(\mathrm{ILCR})$ from $\mathrm{As}$ and $\mathrm{Pb}$ intake. The horizontal lines represent the medians. The extreme HIvalue 24 of sample HN10 from the Red River area is not plotted.

Both, cancer risks and non-cancer risks from rice consumption, are considerably higher than the tolerable health risks levels. Our results show an urgent need to lower the uptake of potentially harmful elements into rice grains. In addition to the critical comments given above, the indexes may deliver only rough risk estimates for several reasons. The addition of single elements quotients to get the health risk seems questionable due to the lack of knowledge regarding the interaction among elements and other harmful compounds (Nordberg et al. 2015a). In addition, more sources of harmful elements such as other food sources, drinking water, air pollution among others, aggravate the situation. All calculations in this paper are done for adult lifetime exposure without considering the special stages of infancy, child, and old age. According to Liao et al. (2018), these sensible age groups may have an elevated cancer risk even with lower contaminant intake because the cancer slope factor for these groups is higher. 
The system helps to get a relative risk contribution of every harmful substance and allows to compare the risk for different rice samples.

\section{Conclusion}

Elements are transported within the plant through charge interactions on the cell walls. As a result, concentrations of most cationic elements gradually decrease with an increasing distance from the root in the order: shoot $>$ husk > grain. Exceptions are Cd, Mg, Zn, S, Cu, and Mo, whose concentrations decrease in the order: shoot $>$ grain $>$ husk. In particular, the P concentration decreases in the order grain > shoot > husk. The preferential transfer of $\mathrm{S}$, Mo, and $P$ into the grain is probably due to their anionic character and their electrostatic repulsion at the negative loaded cell walls. The easily transport of $\mathrm{Cu}, \mathrm{Zn}$ and $\mathrm{Ni}$ into the grains may be due to the formation of soluble organic complexes in the sap.

Health risk calculations on basis of the daily intake of As, $\mathrm{Cd}, \mathrm{Pb}, \mathrm{Cu}, \mathrm{Mn}, \mathrm{Mo}$, and $\mathrm{Ni}$ by rice consumption indicate that, all unpolished rice grains are within unsafe levels of non-cancer risk with a chronic cumulative Hazard Index $(\mathrm{HI})$ ranging between 1.4 and 8.4 (with one sample even reaching 21). The risk level of $H I=1$ should not be exceeded. A 18\% of all samples surpass the high-risk level of $\mathrm{HI}=5$ : in Huong River area in 50\%, Red River area in 26\%, and the Mekong River area in 14\%. The elements Cd, As, $\mathrm{Mn}$, and $\mathrm{Pb}$ are the main contributors to the HI-value contributing in 64 - 97\% of the $\mathrm{HI}$ (average 86\%). These elements should be included into any health risk study for rice consumption. Further possibilities to lower their uptake by rice grains should be explored.

The cancer risk index ( $\left.\sum \mathrm{ILCR}\right)$ of $\mathrm{As}$ and $\mathrm{Pb}$ fluctuates from $9 \times 10^{-4}$ to $64 \times 10^{-4}$ (mean $22 \times 10^{-4}$ ). It is considerably higher than the acceptable cancer risk threshold between $10^{-4}$ and $10^{-6}$. The mean $\sum$ ILCR values are $21 \times 10^{-4}$ of Mekong River grain, $24 \times 10^{-4}$ of Red River grain, and $31 \times$ $10^{-4}$ of Huong River grain. Arsenic is the most potential carcinogenic risk factor for rice consumption in Vietnam.

\section{Acknowledgement}

The authors thank the Department Sedimentology \& Environmental Geology, Faculty of Geoscience and Geography, Göttingen University for providing chemicals and instruments for the analytical work.

\section{References}

[1] Abedin, M. J., Feldmann J, Meharg, A. A. (2002). Uptake kinetics of arsenic species in rice plants. Journal of Plant Physiology, 128, 1120-1128. https://doi.org/ 10.1104/pp.010733

[2] Bhattacharya, P., Samal, A. C., Majumdar, J., Santra, S. C. (2010). Arsenic contamination in rice, wheat, pulses, and vegetables: A study in an arsenic affected area of West Bengal, India. Water Air Soil \& Pollution, 213, 3-13. https://doi.org/10.1007/S11270-0100361-9

[3] Biswas, A., Biswas, S., Santra, S. C. (2014). Arsenic in irrigated water, soil, and rice: perspective of the cropping seasons. Paddy and Water Environment, 12, 407-412. https://doi.org/10.1007/S10333-013-03969

[4] Blume, H.P., Brümmer, G. W., Fleige, H., Horn, R., Kandeler, E., Kögel-Knabner, I., et al. (2016). Soil Science (16th edn). Springer, Germany.

[5] FAO (2018). Rice market monitor, Vol XXI No. 1. http://www.fao.org/3/i9243en/I9243EN.pdf. Accessed 16 July 2020.

[6] EFSA (2009). Cadmium in food - Scientific opinion of the Panel on Contaminants in the Food Chain. EFSA Journal, 7:980. https://doi.org/10.2903/j.efsa.2009. 980

[7] EFSA (2010). Scientific Opinion on Lead in Food - EFSA Panel on Contaminants in the Food Chain (CONTAM). EFSA Journal, 8:1570. https://doi.org/10.2903/j.efsa. 2010.1570

[8] Fakhri, Y., Bjørklund, G., Bandpei, A. M., Chirumbolo, S., Keramati, H., Hosseini, P. R., et al. (2018). Concentrations of arsenic and lead in rice (Oryza sativa L.) in Iran: A systematic review and carcinogenic risk assessment. Food and Chemistry Toxicology, 113, 267-277. https://doi.org/10.1016/j.fct.2018.01.018

[9] Greger, M. (2004). Metal availability, uptake, transport and accumulation in plants. In Prasad MNV (Ed.), Heavy Metal Stress in Plants - From Biomolecules to Ecosystems. Springer, Berlin, pp 1-27.

[10] Ha, C.T.T. (2011). Survey on heavy metals contaminated soils in Thai Nguyen and Hung Yen provinces in Northern Vietnam. Journal of Vietnam Environment, 1, 34-39. https://doi.org/10.13141/jve. vol1.no1.pp34-39

[11] Herawati, N., Suzuki, S., Hayashi, K., Rivai, I. F., Koyama, H. (2000). Cadmium, copper, and zinc levels in rice and soil of Japan, Indonesia, and China by soil type. Bulletin of Environmental Contamination and Toxicology, 64, 33-39. https://doi.org/10.1007/ s001289910006

[12] Huong, N.T.L, Ohtsubo, M., Li, L., Higashi, T., Kanayama, M., Nakano, A. (2008). Heavy metal contamination of soil and rice in wastewater-irrigated paddy field in a suburban area of Hanoi, Vietnam. Communications in Soil Science and Plant Analysis, 13, 205-215. https://doi.org/10.11362/ jcssjclayscience1960.13.205

[13] Jaishankar, M., Tseten, T., Anbalagan, N., Mathew, B. B., Beeregowda, K. N. (2014). Toxicity, mechanism and health effects of some heavy metals. Interdisciplinary 
toxicology, 7, 60-72. https://doi.org/10.2478/intox2014-0009

[14] Khan, N. I., Owens, G., Bruce, D., Naidu, R. (2009). Human arsenic exposure and risk assessment at the landscape level: a review. Environmental Geochemistry and Health, 31, 143-166. https://doi.org/10.1007/S10653-008-9240-3

[15] Kumarathilaka, P., Seneweera, S., Meharg, A., Bundschuh, J. (2018). Arsenic speciation dynamics in paddy rice soil-water environment: sources, physicochemical, and biological factors - A review. Water Research, 140, 403-414. https://doi.org/10.1016/ j.watres.2018.04.034

[16] Kunhikrishnan, A., Go, W. R., Park, J. H., Kim, K. R., Kim, H. S., Kim, K. H., et al. (2015). Heavy metal(loid) levels in paddy soils and brown rice in Korea. Korean Journal of Soil Science and Fertilizer, 48. https://doi.org/ 10.7745/KJSSF.2015.48.5.515

[17] Kuramata, M., Abe, T., Matsumoto, S., Ishikawa, S. (2011). Arsenic accumulation and speciation in Japanese paddy rice cultivars. Soil Science and Plant Nutrition, 57, 248-258. https://doi.org/10.1080/ 00380768.2011 .565479

[18] Mao C, Song Y, Chen L, Ji J, Li J, Yuan X, et al. (2019) Human health risks of heavy metals in paddy rice based on transfer characteristics of heavy metals from soil to rice. CATENA 175:339-348. https://doi.org/10.1016/j.catena.2018.12.029

[19] Marquez J., Pourret O., Faucon, M-P, Weber, S., Bich, T., Hoang, H., et al. (2018). Effect of cadmium, copper and lead on the growth of rice in the coal mining region of Quang Ninh, Cam-Pha (Vietnam). Sustainability, $\quad 10 . \quad$ https://doi.org/10.3390/ su10061758

[20] McCauley, A., Jones, C., Olson-Rutz, K. (2017). Soil pH and organic matter. Nutrient Management 8. http://landresources.montana.edu/nm/documents/ NM8.pdf. Accessed 27 March 2019

[21] Meharg, A. A., Zhao, F. J. (2012). Arsenic \& Rice. Springer, Dordrecht, Heidelberg, London, New York.

[22] Meng, J., Zhong, L., Wang, L., Liu, X., Tang, C., Chen, H., et al. (2018). Contrasting effects of alkaline amendments on the bioavailability and uptake of $\mathrm{Cd}$ in rice plants in a Cd-contaminated acid paddy soil. Environmental Science and Pollution Research, 25, 8827-8835. https://doi.org/10.1007/S11356-017$1148-y$

[23] Nguyen, T. P., Ruppert, H., Sauer, B., Pasold, T. (2020a). Harmful and nutrient elements in paddy soils and their transfer into rice grains (Oryza sativa) along two river systems in northern and central Vietnam. Environmental Geochemistry and Health, 42, 191 207. https://doi.org/10.1007/S10653-019-00333-3

[24] Nguyen, T. P., Ruppert, H., Pasold, T., Sauer, B. (2020b). Paddy soil geochemistry, uptake of trace elements by rice grains (Oryza sativa) and resulting health risks in the Mekong River Delta, Vietnam. Environmental Geochemistry and Health, 42, $2377-$ 2397. https://doi.org/10.1007/S10653-019-00456-7

[25] Nordberg, G. F., Gerhardsson, L., Mumtaz, M. M., Ruiz, P., Fowler, B. A. (2015b). Interactions and mixtures in metal toxicology. In Nordberg, G. F., Fowler, B. A., Nordberg, M. (ed), Handbook on the Toxicology of Metals (pp. 213-238). Elsevier, UK,

[26] Norton, G. J., Williams, P. N., Adomako, E. E., Price, A. H., Zhu, Y., Zhao, F. J., et al. (2014). Lead in rice: Analysis of baseline lead levels in market and field collected rice grains. Science of the Total Environment, 485-486:428-434. https://doi.org/ 10.1016/j.scitotenv.2014.03.090

[27] OEHHA - Office of Environmental Health Hazard Assessment, 2009. Technical Support Document for Cancer Potency Factors: Methodologies for derivation, listing of available values, and adjustments to allow for early life stage exposures. https://oehha.ca.gov/media/downloads/crnr/tsdcanc erpotency.pdf. Accessed 22 June 2020

[28] Phuong NM, Kang Y, Sakurai K, Iwasaki K, Kien CN, Noi NV, et al. (2010) Levels and chemical forms of heavy metals in soils from Red River Delta, Vietnam. Water, Air, \& Soil Pollution 207:319-332. https://doi.org/ 10.1007/S11270-009-0139-0

[29] Rahman, M. A., Hasegawa, H. (2011). High levels of inorganic arsenic in rice in areas where arseniccontaminated water is used for irrigation and cooking. Sci Total Environ, 409, 4645-4655. https://doi.org/10.1016/j.scitotenv.2011.07.068

[30] Rizwan M, Ali S, Adrees M, Rizvi H, Zia-ur-Rehman M, Hannan F, et al. (2016) Cadmium stress in rice: toxic effects, tolerance mechanisms, and management: a critical review. Environmental Science and Pollution Research 23:17859-17879. https://doi.org/10.1007/ S11356-016-6436-4

[31] Seyfferth, A. L., McCurdy, S., Schaefer, M. V., Fendorf, S. (2014). Arsenic concentrations in paddy soil and rice and health implications for major rice-growing regions of Cambodia. Environmental Science \& Technology, 48, 4699-4706. https://doi.org/10.1021/ es405016t

[32] Shraim, A. M. (2017). Rice is a potential dietary source of not only arsenic but also other toxic elements like lead and chromium. Arabian Journal of Chemistry, 10, S3434-S3443.

https://doi.org/10.1016/j.arabjc.2014.02.004

[33] Simmons, R. W., Pongsakul, P., Saiyasitpanich, D., Klinphoklap, S. (2005). Elevated levels of cadmium and zinc in paddy soils and elevated levels of cadmium in rice grain downstream of a zinc mineralized area in Thailand: Implications for public 
health. Environmental Geochemistry and Health, 27, 501-511. https://doi.org/10.1007/S10653-005-7857Z

[34] Smith, A. H., Marshall, G., Yuan, Y., Ferreccio, C., Liaw, J., von Ehrenstein, O., et al. (2006). Increased mortality from lung cancer and bronchiectasis in young adults after exposure to arsenic in utero and in early childhood. Environmental Health Perspectives, 114, 1293-1296. https://doi.org/10.1289/ehp.8832

[35] Sriprachote, A., Kanyawongha, P., Ochiai, K., Matoh, T. (2012). Current situation of cadmium-polluted paddy soil, rice and soybean in the Mae Sot District, Tak Province, Thailand. Soil Science and Plant Nutrition, 58, 349-359. https://doi.org/10.1080/00380768. 2012.686435

[36] Suriyagoda, L. D. B., Dittert, K., Lambers, H. (2018). Mechanism of arsenic uptake, translocation and plant resistance to accumulate arsenic in rice grains. Agriculture, Ecosystems \& Environment, 253, 23-37. https://doi.org/10.1016/j.agee.2017.10.017

[37] USEPA (1989). Risk Assessment Guide for Superfund (RAGS): volume I, Human Health Evaluation ManualPart A, baseline risk assessment. https://www.epa.gov/sites/production/files/201509/documents/rags_a.pdf. Accessed 19 March 2019

[38] Vinh, N. C., Oborn, I., Ha, P. Q., Minh, N. D., Hough, R.
L., Khai, N. M., et al. (2012). Potential environment and public health risk due to contamination of heavy metals from industrial waste water in Lam Thao, Phu Tho, Vietnam. American Journal of Environmental Sciences, 8, 71-78.

[39] Wan, Y., Camara, A. Y., Yu, Y., Wang, Q., Guo, T., Zhu, L., et al. (2018). Cadmium dynamics in soil pore water and uptake by rice: Influences of soil-applied selenite with different water managements. Environmental Pollution, 240, 523-533. https://doi.org/10.1016/ j.envpol.2018.04.044

[40] Xiao, L., Guan, D., Peart, M. R., Chen, Y., Li, Q., Dai, J. (2017). The influence of bioavailable heavy metals and microbial parameters of soil on the metal accumulation in rice grain. Chemosphere, 185, 868878. https://doi.org/10.1016/j.chemosphere.2017. 07.096

[41] Zarcinas, B. A., Ishak, C. F., McLaughlin, M. J., Cozens, G. (2004a). Heavy metals in soils and crops in Southeast Asia. Environmental Geochemistry and Health, 26, 343-357. https://doi.org/10.1007/S10653005-4669-0

[42] Zarcinas, B. A., Pongsakul, P., McLaughlin, M. J., Cozens, G. (2004b). Heavy metals in soils and crops in Southeast Asia 2. Thailand. Environmental Geochemistry and Health, 26, 359-371. https://doi.org/10.1007/S10653-005-4670 